\title{
Potential drug-drug interactions in the neurology ward of a tertiary care hospital in Peshawar, Pakistan
}

\author{
Roheena Zafar ${ }^{1}$, Kamran A Chishti ${ }^{1}$ and Muhammad Zahoor ${ }^{2}$ \\ ${ }^{1}$ Department of Pharmacy, Sarhad University of Science and Information Technology, Peshawar, ${ }^{2}$ Department of Chemistry, \\ University of Malakand, Chakdara, Dir Lower, Pakistan
}

*For correspondence: Email: mohammadzahoorus@yahoo.com

\begin{abstract}
Purpose: To identify and report the prevalence of potential drug-drug interactions (pDDIs) in a neurology ward, as well as their levels and association with risk factors.

Methods: The study was conducted in the neurology ward of Northwest General Hospital Peshawar, Pakistan. Medical records of 205 randomly selected patients were retrospectively reviewed for potential drug-drug interactions using Micromedex Drug-Reax Software.

Results: The total number of interactions identified were 633. About $96 \%$ of the patients showed at least one type of potential interaction regardless of its severity. The identified pDDls were categorized on the basis of severity, scientific evidence and onset. Based on severity, of the total of $633 \mathrm{pDDls}, 62.2$ $\%$ were of major type while $31.8 \%$ were of moderate type. On the basis of scientific evidence, $16.42 \%$ were excellent type, $32.22 \%$ in good category while fair category was the highest $(55.60 \%)$. The onset categories such as rapid (27.64\%), delayed (24.96\%) and non-specified onset (53.71\%) were also noted.

Conclusion: Computerized DDIs programs are very helpful in minimizing harmful drug interactions. With this type of program, this better patient health outcomes can be achieved.
\end{abstract}

Keywords: Drug-drug interaction, Patients, Drug reaction

Tropical Journal of Pharmaceutical Research is indexed by Science Citation Index (SciSearch), Scopus, International Pharmaceutical Abstract, Chemical Abstracts, Embase, Index Copernicus, EBSCO, African Index Medicus, JournalSeek, Journal Citation Reports/Science Edition, Directory of Open Access Journals (DOAJ), African Journal Online, Bioline International, Open-J-Gate and Pharmacy Abstracts

\section{INTRODUCTION}

Scientific discoveries, technological advancements and recent developments in pharmacotherapy, have made a substantial impact in improving-the quality of patient's-life. Due to such advancements in pharmacotherapy, a-number-of medications are available-and their use is increasing day by day. The drugs-are capable of producing therapeutic effects on one hand but on other hand they can also produce many undesirable effects [1]. Such adverse type of-effects-are undesirable. Strand et al [2] has identified eight types of drug-related- problems. Amongst them the major problem is drug-drug interaction (DDIs). The Drug-Drug-interactionarises when a drug interact with another drug and alters or modifies its effect if administered together [3]. DDIs may-be beneficial or harmful. The harmful DDIs may lead to the adverse drug reactions and will leads to negative consequences in patients especially in hospitalized patients, as they usually suffer from severe illnesses with multiple disorders. Generally the term potential drug-drug interaction is also used in parallel, as every DDI caries the risk to cause negative outcomes bur are generally predictable which can therefore be avoidable or manageable [4]. 
Owing to the importance of DDIs, the study was aimed to identify and to investigate the potential adverse outcomes in most commonly clinically important, potential DDIs in neurology ward in a tertiary care hospital, Khyber Pakhtunkhwa, Pakistan.

\section{METHODS}

\section{Settings}

This research was carried out in neurology ward of Northwest General Hospital \& Research Center, Peshawar, Khyber Pakhtunkhwa, Pakistan. Northwest General Hospital \& Research center is 306 bedded tertiary care hospital that provides specialized health care and referral services to all the population in and around Kyber Pakhtunkhwa.

\section{Design and study population}

This was a cross-sectional retrospective study, carried out by using automated medication records of 205 randomly selected patients who had been admitted to neurology ward of hospital during 1 year period from $1^{\text {st }}$ January, 2015 to $31^{\text {st }}$ Dec, 2015. Incomplete patients' records were excluded from the study.

\section{Data collection and screening of pDDls}

The study protocols complied with the guidelines of the Declaration of Helsinki [5,6], and the ethical committee of North West General Hospital, Peshawar granted approval (no. NWHP/Eth-H-087/15) for the conduct of this study. In-patients' records were reviewed and screened retrospectively for pDDIs using computerized drug interaction and information system, the Micromedex Drug-Reax System (Thomson Reuters Healthcare Inc, Greenwood Village, Colorado, USA) [7].

The entries of all prescribed drugs to the selected patients from the date of admission till the date of discharge were made. Patients with major severity were screened out. Categorization [7] of clinically potential DDls was made on basis of Onset, severity and scientific evidence. Their detail is given below:

\section{Onset}

- $\quad$ Rapid: Onset of adverse effects or clinical conflict are expected to occur within 24 hour of administration and their management requires immediate action.
Delayed: Onset of adverse effects or clinical conflict that do not appear within 24 hour but occurs days to weeks after the drugs administration.

\section{Severity}

- Contraindicated: The drug combination is contraindicated for concurrent use.

- Major: Such type of interactions may be life-threatening and fatal, require immediate treatment in order to prevent or minimize the serious negative adverse effects.

Moderate: Moderate interactions may exacerbate the patient's condition and may require change in therapy.

- Minor: Limited clinical effects and generally will not require any major change in therapy.

\section{Documentation}

$\bullet$

Excellent: Controlled studies have clearly established the existence of the interaction.

- Good: Documentation strongly suggests the existence of interaction but there is lack of well controlled studies.

Fair: Available documentation is poor but on the basis pharmacological considerations the interaction is suspected to exist and data is available from pharmacologically similar drug.

- Poor: Documentation is very limited and interaction may occur theoretically, as very few cases are reported.

- Unlikely: Documentation is very poor and lacks a sound pharmacological basis.

\section{Statistical analysis}

Data was analyzed statistically by using Graph Pad Prism 5 (GraphPad Software Inc. San Diego CA, USA). The Chi-square test was used to analyze the data. A $P$ value $<0.05$ was defined as statistically significant.

Trop J Pharm Res, October 2017; 16(10): 2522 


\section{RESULTS}

\section{Patient's general characteristics}

In this study the potential DDIs were evaluated for 205 patients in neurological ward. The gender, age etc. details of the selected patients are given in Table 1.

Table 1: Patient's general characteristics

\begin{tabular}{ll}
\hline $\begin{array}{l}\text { Characteristics } \\
\text { of patient }\end{array}$ & $\begin{array}{l}\text { Frequency } \\
\text { (n, \%) }\end{array}$ \\
\hline $\begin{array}{l}\text { Gender } \\
\text { Male }\end{array}$ & $114(56)$ \\
Female & $91(44)$ \\
Age (years) & \\
$\leq 20$ & $38(19)$ \\
$21-39$ & $68(33)$ \\
$40-59$ & $83(40)$ \\
$\geq 60$ & $16(08)$ \\
Hospital stay (days) & \\
$\leq 3$ & $72(35)$ \\
$4-6$ & $98(48)$ \\
$\geq 7$ & $35(17)$ \\
Prescribed medications & \\
per patient & \\
$\leq 4$ & $32(146)$ \\
$5-6$ & $74(36)$ \\
$\geq 7$ & $99(48)$ \\
\hline
\end{tabular}

\section{Prevalence of pDDIs}

The total number of interactions identified were 633. Out of 205 patients, 197 had at least one pDDIs regardless of type of severity. In 8 patients no interaction were observed.

\section{Levels of pDDls}

The identified pDDIs were categorized on the basis of level of severity, scientific evidence and onset [7] and are given table 2. Among 633
pDDIs, most of were major (394, $62.2 \%)$ or moderate severity $(201,31.8 \%)$; excellent (104, $16.42 \%)$ good $(204,32.22 \%)$ or fair $(352,55.60$ $\%)$ type of scientific evidence; rapid (175, 27.64 $\%$ delayed $(158,24.96 \%)$ or non-specified onset $(340,53.71 \%)$

\section{Commonly interacting combinations}

About 69 interacting pairs were identified in this study. There were top 15 major frequently occurring interacting pairs of pDDIs (Table 3 ).

\section{DISCUSSION}

This study-represents the importance of computer software program for checking the potential DDIs. About 633 drug interactions were identified from clinical records of 205 hospitalized patients admitted in neurology ward, in which 96 $\%$ patients showed at least one potential drugdrug interaction during hospitalization regardless of severity of the interaction.

Most of pDDIs were of major severity type (62.2 $\%$ ) and were of serious concern. Medically they are of prime importance for practitioners as they produces negative outcomes. Co-administration with carbapenem antibiotics may substantially decrease-the concentrations of-valproic-acid in serum. However simultaneous use of valproic acid with carbapenem is generally not recommended [8]. There is risk of epidural or spinal-hematoma if Aspirin and Enoxaparin combination is used in patients receiving neuraxial-anesthesia or spinal-puncture [9]. While using haloperidol and tramadol combination, one must be cautious, as it can reduce the seizure threshold and thus there is an increased risk of seizures [10].

Table 2: Distribution of identified potential drug-drug interactions on the basis of Levels

\begin{tabular}{lcccc}
\hline Level & $\mathbf{N}$ & $\%$ & $\mathbf{x}^{2}$ & $\boldsymbol{P}$-value \\
\hline Severity & & & & \\
Contraindicated & 021 & 03.32 & 607.866 & $<0.001$ \\
Major & 394 & 62.24 & & \\
Moderate & 201 & 31.75 & & \\
Minor & 017 & 02.68 & & \\
Documentation & & & & \\
Excellent & 104 & 16.43 & & \\
Good & 204 & 32.22 & & \\
Fair & 352 & 55.61 & & \\
Onset & & & & \\
Rapid & 165 & 26.06 & & \\
Delayed & 158 & 24.96 & & \\
Non specified & 340 & 53.71 & & \\
\hline \multicolumn{1}{c}{ Chi-square test was used and $p<0.05$ was considered statistically significant }
\end{tabular}


Table 3: Identified potential drug-drug interactions and their adverse out comes

\begin{tabular}{|c|c|c|c|c|c|}
\hline Interaction & $n$ & Severity & Onset & Evidence & Potential adverse outcomes \\
\hline $\begin{array}{l}\text { Meropenem + valproic } \\
\text { Acid }\end{array}$ & 58 & Major & Rapid & Excellent & Loss of seizure control \\
\hline $\begin{array}{l}\text { Tramadol } \quad+ \\
\text { Metoclopramide }\end{array}$ & 56 & Major & $\begin{array}{l}\text { Not } \\
\text { Specified }\end{array}$ & Fair & Increase the risk for seizure. \\
\hline Haloperidol + Tramadol & 48 & Major & Rapid & Fair & Increase the risk for seizure. \\
\hline Aspirin + Enoxaparin & 43 & Major & $\begin{array}{l}\text { Not } \\
\text { Specified }\end{array}$ & Fair & Increase the risk for bleeding. \\
\hline Clopidogrel + Enoxaparin & 37 & Major & $\begin{array}{l}\text { Not } \\
\text { Specified }\end{array}$ & Fair & Increase the risk for bleeding. \\
\hline Diazepam + Phenytoin & 32 & Major & $\begin{array}{l}\text { Not } \\
\text { Specified }\end{array}$ & Good & $\begin{array}{l}\text { Results in altered serum phenytoin } \\
\text { concentration }\end{array}$ \\
\hline Tramadol + Linezolid & 22 & Major & $\begin{array}{l}\text { Not } \\
\text { Specified }\end{array}$ & Good & $\begin{array}{l}\text { Increase the risk of Serotonin } \\
\text { syndrome. }\end{array}$ \\
\hline Aspirin + Clopidogrel & 19 & Major & $\begin{array}{l}\text { Not } \\
\text { Specified }\end{array}$ & Fair & Increase the risk of bleeding. \\
\hline Diclofenac + Enoxaparin & 17 & Major & $\begin{array}{l}\text { Not } \\
\text { Specified }\end{array}$ & Good & Increase the risk of bleeding. \\
\hline Heparin + Aspirin & 10 & Major & $\begin{array}{l}\text { Not } \\
\text { Specified }\end{array}$ & Fair & Increase the risk of bleeding. \\
\hline Enoxaparin + Warfarin & 10 & Major & $\begin{array}{l}\text { Not } \\
\text { Specified }\end{array}$ & Fair & Increase the risk of bleeding. \\
\hline Escitralopram + Tramadol & 7 & Major & $\begin{array}{l}\text { Not } \\
\text { Specified }\end{array}$ & Fair & $\begin{array}{l}\text { Increase the risk of seizures, serotonin } \\
\text { syndrome, opioid toxicity and Increase } \\
\text { concentration of tramadol. }\end{array}$ \\
\hline $\begin{array}{l}\text { Ciprofloxacin } \\
\text { Prochlorperazine }\end{array}$ & 5 & Major & $\begin{array}{l}\text { Not } \\
\text { Specified }\end{array}$ & Fair & $\begin{array}{l}\text { Increase risk of } \\
\text { prolongation. }\end{array}$ \\
\hline Valproic Acid + Imepenem & 5 & Major & $\begin{array}{l}\text { Not } \\
\text { Specified }\end{array}$ & Good & $\begin{array}{l}\text { Loss of anticonvulsant effect due to } \\
\text { decrease valproic Acid concentration. }\end{array}$ \\
\hline Amikacin + Colistimethate & 3 & Major & Rapid & Fair & Causes Respiratory depression. \\
\hline
\end{tabular}

Similarly, the co-administration of diazepam and phenytoin results in phenytoin toxicity [11]. The intake of linzolid with such medicines that results in increased concentrations of serotonin in the central nervous system may lead to Serotonin toxicity [12]. The combination of anticoagulants and NSAID would increase the peri-operative risk of bleeding problems [13].

There are many drug-drug interactions compendia which have been classified on the basis of their levels of severity, onset, evidence based scientific literatures, management-optionsor-their-combinations $[9,14,15]$.

The incidence of DDIs in different countries varies from $6 \%$ to $70 \%$ due to variability in methodologies and settings. These variations arises due differences in design of research studies, locations of study (e.g., hospitals, emergency rooms, community settings, nursing homes), population's characteristics (e.g., elderly, adults), availability of advanced clinical pharmacy services and the most important, accessibility and use of electronic DDIs. Screening programs. Hospitalized patients usually suffer from severe illnesses and multiple disorders as compared to community and outpatient settings. Due to this reason, DDIs-areless likely-to-occur in outdoor patients or community setups as compared to hospitalized patients. Therefore their negative outcomes would be-more-severe in admitted patients. Generally-large-number of medications-areprescribed to admitted patients. Due to complextherapeutic regimens, DDIs need more attention in hospitalized patients.

Advanced computer software systems are now available, with the aid of which, pDDIs can be easily identified and managed by replacing a particular drug with another related one, by altering the dose amount or by close monitoring the clinical signs and laboratory test outcomes [7-15]. Pharmacists can optimize the pharmacotherapy by applying their professional knowledge, skills and using the computerized scientific evidence based software programs, which would be helpful to minimize or prevent the serious negative consequences of DDIs [16,17]. These results suggest that these patients are at higher risk to negative consequences of these identified drug interactions therefore patients' clinical conditions needs very careful and close monitoring.

\section{Limitations of the study}

Although there much work remains to be done, and important findings have been generated in 
this study, it was limited to only those patients admitted in the neurology ward of the hospital. To obtain a clearer picture of the drug-drug interaction, data for out-patients are also needed. Future studies should address this as pet.

\section{CONCLUSION}

Comparatively high numbers of incidence of pDDIs (major severity) were recorded in the neurology ward of the study site. To avoid the negative consequences of pDDls, computational software are helpful tools but their successful use is tied to medical experience, knowledge of relevant patient-related factors as well as establishment of drug information centers. The identified pDDls in this study are of serious nature and are harmful to patients. Therefore, the medication orders should be screened and analyzed by a clinical pharmacist, at least for major DDIs, before the mediation is dispensed. Thereafter, adverse drug reactions should be carefully monitored.

\section{DECLARATIONS}

\section{Acknowledgement}

The authors are very grateful to the consultants and other staff of neurology ward, Northwest General Hospital and Research Center, Peshawar, Pakistan for their cooperation in securing access to hospital record and financial support.

\section{Conflict of Interest}

No conflict of interest associated with this work.

\section{Contribution of Authors}

The authors declare that this work was done by the authors named in this article and all liabilities pertaining to claims relating to the content of this article will be borne by them.

\section{Open Access}

This is an Open Access article that uses a funding model which does not charge readers or their institutions for access and distributed under the terms of the Creative Commons Attribution License (http://creativecommons.org/licenses/by/ 4.0) and the Budapest Open Access Initiative (http://www.budapestopenaccessinitiative.org/rea d), which permit unrestricted use, distribution, and reproduction in any medium, provided the original work is properly credited.

\section{REFERENCES}

1. Edwards IR, Aronson JK. Adverse drug reactions: definitions, diagnosis, and management. The Lancet 2000; 356(9237): 1255-1259.

2. Hepler $C D$, Strand $L M$. Opportunities and responsibilities in pharmaceutical care. Am J Hosp Pharm 1990; 47 (3): 533-543.

3. Baxter K, Preston CL. Stockley's drug interactions: Pharmaceutical Press London; 2010.

4. Cruciol-Souza JM, Thomson JC. A pharmacoepidemiologic study of drug interactions in a Brazilian teaching hospital. Clinics 2006; 61(6): 515-520.

5. World Medical Association Declaration of Helsinki; Ethical Principles for Medical Research Involving Human Subjects. Bull WHO 2001; 79(4): 373-374.

6. Naderi MM, Sarvari A, Milanifar A, Boroujeni SB, Akhondi MM. Regulations and Ethical Considerations in Animal Experiments: International Laws and Islamic Perspectives. Avicenna J Med Biotechnol 2012; 4(3): 114-120.

7. Micromedex Drug-Reax® System. [Database on $C D$ ROM].Volume 150. Greenwood Village, Colo: Truven Health Analytics Inc; 2015.

8. Coves-Orts FJ, Borras-Blasco J, Navarro-Ruiz A, MurciaLopez A, Palacios-Ortega F. Acute seizures due to a probable interaction between valproic acid and meropenem. Ann Pharmacother 2005; 39(3): 533-537.

9. Merlo J, Liedholm H, Lindblad U, Bjorck-Linne A, Falt J, Lindberg G, Melander A. Prescriptions with potential drug interactions dispensed at Swedish pharmacies in January 1999: cross sectional study. BMJ 2001; 323 (7310): 427-428.

10. Gardner JS, Blough D, Drinkard CR, Shatin D, Anderson G, Graham D, Alderfer R. Tramadol and seizures: a surveillance study in a managed care population. Pharmacotherapy 2000; 20(12): 1423-1431.

11. Murphy A, Wilbur K. Phenytoin-diazepam interaction. Ann Pharmacother 2003; 37 (5): 659-663.

12. Lawrence KR, Adra M, Gillman PK. Serotonin toxicity associated with the use of linezolid: a review of postmarketing data. Clin Infect Dis 2006; 42 (11): 15781583.

13. Faunø P, Petersen KD, Husted SE. Increased blood loss after preoperative NSAID: Retrospective study of 186 hip arthroplasties. Acta Orthopaed Scand 1993; 64 (5): 522-524.

14. Hansten PD, Horn JR. Drug interactions: analysis and management: Wolters Kluwer Health. 2007.

15. Tatro DS. Drug Interaction Facts: 2001 Edition: Facts and Comparisons 2000.

16. Pakistan Country Profile. World Health Organization (WHO) 2013. Available from http://www.who.int/ countries/pak/en/. Accessed Jan 20, 2015.

17. Health Systems Profile- Pakistan. World Health Organization (WHO). http://gis.emro.who.int/HealthSystemObservatory/PDF/P 
Zafar et al

akistan/Health\%20system

\%20organization.pdf.

Accessed Jan 20, 2015.

Trop J Pharm Res, October 2017; 16(10): 2526 